\title{
INTERACTION OF BUMETANIDE AND KANAMYCIN
}

IWAO OHTANI, M.D., KOHSEI OHTSUKI, M.D., TAKEO OMATA, M.D.

AND JIN OUCHI, M.D.

Department of Otorhinolaryngology, Fukushima Medical College, Fukushima

(Director: J. Ouchi, M.D.)

TAKEO SAITO, M.D.

Department of Pathology, Tohoku Dental University, Koriyama (Director: T. Saito, M.D.)

The absolute diuretic potency of bumetanide (BUN) is 40-60 times that of furosemide (FM). When dosage of two drugs clinically used are considered, the relative ototoxic potency of BUN is very low (about 1/10 of FM). The purpose of this study was to determine the combined ototoxic effect of BUN with kanamycin (KM), and to compare it with that of FM and KM. Doses of BUN were 1/40 and 1/60 of FM. The results obtained were as follows.

1. Severe damage of the outer hair cell occurred in rabbits following the combined administration of BUN and KM. No damage of the outer hair cells was detectable when BUN or KM were used alone with the same dose. The damage of the outer hair cells in rabbits injected with both BUN and KM was approximately equal to that of rabbits receiving both FM and KM. And there was no significant difference in the pattern of the outer hair cell damage between these rabbits.

2. The kidney of rabbits received both BUN and KM also showed the severely damaged lesions of the proximal tubules. And their lesions resembled that found in rabbits received both FM and KM. All of rabbits injected with BUN or KM alone showed the normal renal histological findings under a light microscope.

Therefore, the ototoxicity of BUN in its clinical use is less than that of FM, but the ototoxic effect of BUN used with KM is approximately equal to that of FM with KM. That is, the combined ototoxic effect of the loop diuretics (BUN and FM) and KM may by closely related to the diuresis of diuretics. Severe damage occurred not only in the inner ear but also in the kidney when both BUN and KM were administered to rabbits. It may be, therefore, concluded that the combined administration of BUN and KM (probably another aminoglycoside antibiotics too) would also be dangerous to patients. 


\title{
Bumetanide と Kanamycin 併用による内耳障害 \\ — Furosemide との比較検詰——
}

\author{
福颗県立医科大学耳鼻呕喉科学教室 (主任: 大内 仁教授) \\ 大谷 祣, 大柣好正, 尾股丈夫, 大内 仁 \\ 東北菌科大学病理学教宝（主任：斎藤武郎教授） \\ 晟藤武郎
}

\section{緒言}

Furosemide (FM) や Ethacrynic acid (EA) などの

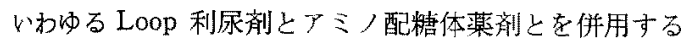
と，内耳障害が著しく増強することが，臨床的にも実験 的にも知られているが，われわれは1 FM とアミノ配糖 体薬剤併用時に内耳のみならず腎においてむ高度の障害 の発現する事奏走報告し，併用時の内耳障害增強性につ いては，FMによるアミノ配糖体薬剤の腎加らの排泄阻 害が重要な因子として作用し，これに腎障害が加わって 急速に悪循環が進行していくため起こると考えた。

Bumetanide (BUN) は最近開発された利尿郕で，FM や $\mathrm{EA}$ 同様， $\mathrm{Na}, \mathrm{Cl}$ の再吸収を抑制することにより利 尿作用を発揮しているが，乙の利尿作用はFM の40〜

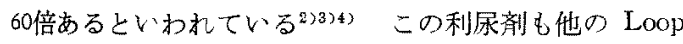
利层剛上同様に，難聴や耳鳴の生ずることが報告されて おり"，実験的にも電気生理学的k CM, AP, EP の低 下をきたすことが報告されている6738793．しかし BUN の内耳に対する作用は，利尿効果家考慮に入机ると FM の約1/10にすぎないといわれている゙ 令回このように にFM に比して内耳毒性が非常に低いBUNを使用し， $\mathrm{KM}$ と併用した際の内耳病態を，既報のFM と KM 併 用時のそれと比較して，Loop 利尿剂乙KM 併用封の内 耳障靚における Loop 利㽷剂の役割について検討を行な い，興味ある知見が得られたので報告する。

\section{奏験方法}

体重 $2.1 \sim 2.8 \mathrm{~kg}$ の白色家鬼30羽老, BUN 群, KM 群，BUN·KM 併用群の3群に分けて使用した。 BUN 群に法 BUN $0.75 \mathrm{mg} / \mathrm{kg}$ ( 5 羽) を，KM 群には KM $200 \mathrm{mg} / \mathrm{kg}$ ( 5 羽) 㕝，BUN.KM 併用群に梳 BUN 0.75 $\mathrm{mg} / \mathrm{kg}$ (10羽) および $0.5 \mathrm{mg} / \mathrm{kg}$ (10羽) にそれぞれ $\mathrm{KM} 200 \mathrm{mg} / \mathrm{kg}$ を併用した。これまでの FM とアミ， 配糖体藥用との併用実験での FM 量を $30 \mathrm{mg} / \mathrm{kg}$ とした
が，BUNの利疗作用はFM の40〜60倍であるため，今 回は BUN の投与量を $30 / 40 \mathrm{mg} / \mathrm{kg}(0.75 \mathrm{mg} / \mathrm{kg})$ 打よ び $30 / 60 \mathrm{mg} / \mathrm{kg}(0.5 \mathrm{mg} / \mathrm{kg})$ とし, 利尿作用学 FM と 问等にして検討を行った、いずれも連日10日閒腹腔内注 射により投与し，最終投与10日後に固定した。しかし併 用の動物では 2 羽が実験途中で死亡したほか，全身状態 雭化のため, 予定生存期間以内に固定せざるを得ないも のが半数以上にみられた。

右耳位 $1 \%$ veronal buffered osmium tetroxide solutionで螖牛を灌流固定し, 蝸牛膜迷路特に外有毛細胞の

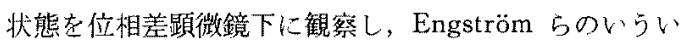
わゆる collapsed cell をもって障害細胞とした。左耳は 10\%緩衝ホルマリンて灌流固定後ツェロイジン包埋によ り連続切片を作製L，H·E染色にて観察した。东た腎は 10\%緩衝ホルマリン固定後 H-E 染色, PAS 染色にて観 祭した。

\section{実験成績}

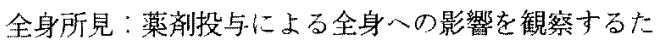
わ，連日全動物の体重を測定した，BUN 群および KM 群では实験終了時の体重の増加は, 無処置動物と差を認 めなかったが，BUN 群で忟与期間中に体重増加がー 時抑制されるものがみられた，一方 BUN.KM併用群で は，企動物で体重が減少し，全身状態の悪化のため子定 生存期間以内に固定せざるを得ないものがみられた。す な⿰七 BUN 0. $75 \mathrm{mg} / \mathrm{kg}$ 併用群では, 10 羽の5ち2 羽 (BK-6, BK-7) が投与期間中に死しし，10日閒投与でき たのは3羽にすぎず，この5ち予定生存期間で固定でき たのは1羽(BK-2)のみであった０.5mg/kg 併用群で は，BUN $0.75 \mathrm{mg} / \mathrm{kg}$ 併用群に比して全身状熊におよぼ 寸影蝆㳗柽く，10羽中9羽に10日間の投与ができ，この 5 5 6 羽 (BK-12, BK-13, BK-15, BK-16, BK-17, BK-20) が予定生存期間で固定した（図 1 ）。 

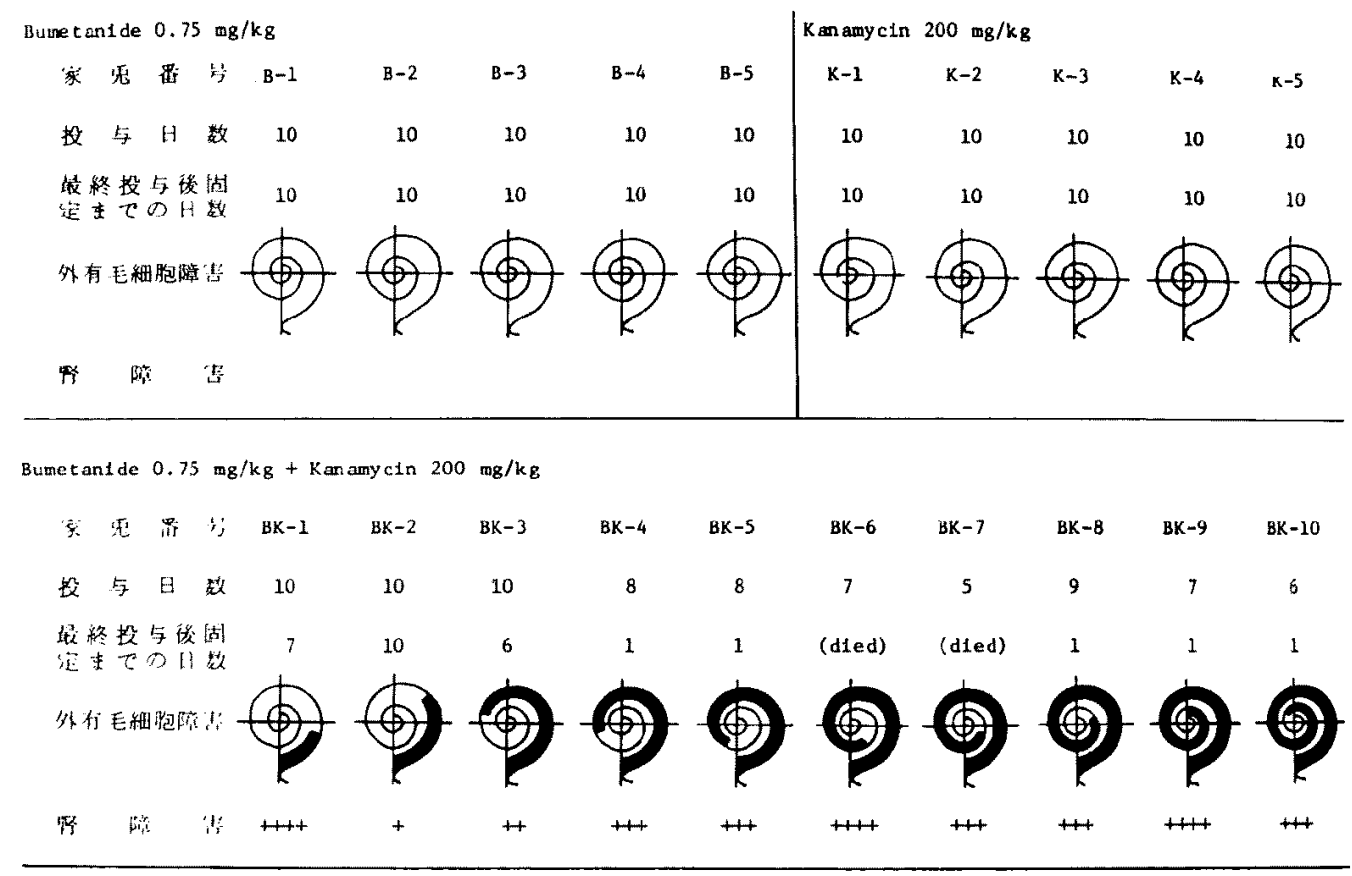

Bumetanide $0.5 \mathrm{mg} / \mathrm{kg}+\mathrm{k}$ anamy cin $200 \mathrm{mg} / \mathrm{kg}$

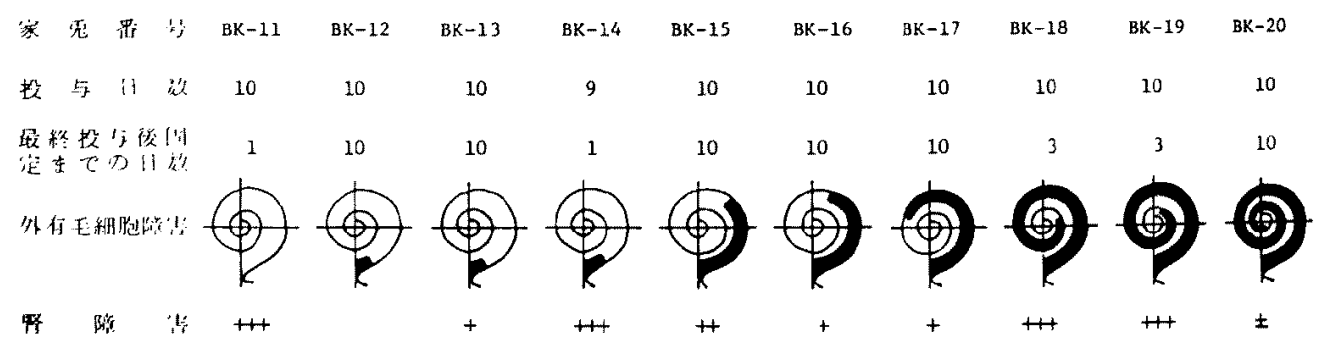

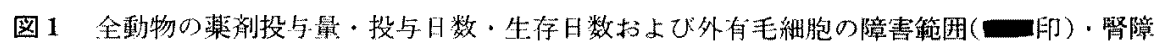
害の程度示す。

内耳所晃：BUN 群㧍よび KM 群では外有毛細胞， 内有毛細胞，血管条など纪は特に障素は烈められなか。 た（図 2)，BUN・KM 併用群で仕特異的に外有老細胞 心障害が認められた。外有毛細胞の障害は併用群20羽中 1 羽 (BK-11) 在除く全動物で認的られ，之の障害は基 底回転で強く，上方回転に向うにつれて軽度となってい た（因 3)，障輩範用恃基底回転の一部に限局しているも のから頭頂回転に波及しているものまで相当のバラッキ がみ又られたが，BUN $0.75 \mathrm{mg} / \mathrm{kg}$ 併用群が $0.5 \mathrm{mg} / \mathrm{kg}$ 併 用群よりも障恝が強い傾向在示していた。 また BUN $0.75 \mathrm{mg} / \mathrm{kg}$ 併用群では，全身状態悪化のため投与日数の
少ない動物がより強い障恝を起こしていた，位相差顕微 鏡下に観察した外有毛紐胞の障害範囲を图1に示した。 内有毛細胞は外有毛細胞の障害が最も広範であった1羽 （BK-20）で障害されているにずなかった（図4）、ま た血管条には midmodiolar section による観察で障害 は諗められなかった。

腎所見：肉眼的には BUN 群および KM 群では異常 を認めなかったが, BUN·KM 併用群では灰白色に腫大 しているものが多かった。

病理組織学的には, BUN 群および KM 群では, とも に明らかな変化はみられなかった（図 5 )。 BUN.KM 併 


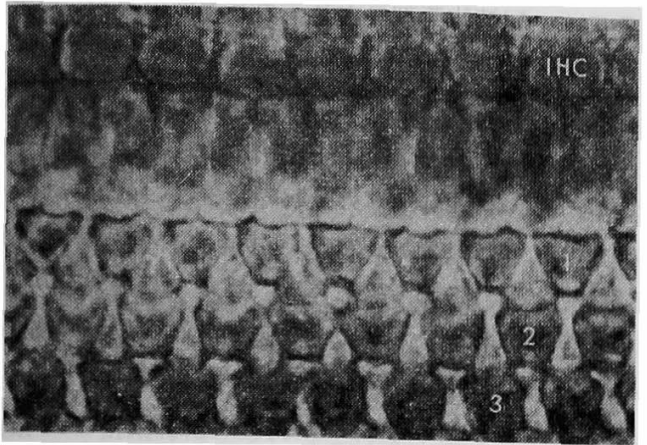

图 2 BUN 0.75mg/kg 10日間投与 (B-1)，基 底回転. 内. 外有毛細胞は正常. $\mathrm{IHC}=$ 内有毛細胞.

$1 ， 2 ， 3$ 外有毛細胞 1，2，3 列。

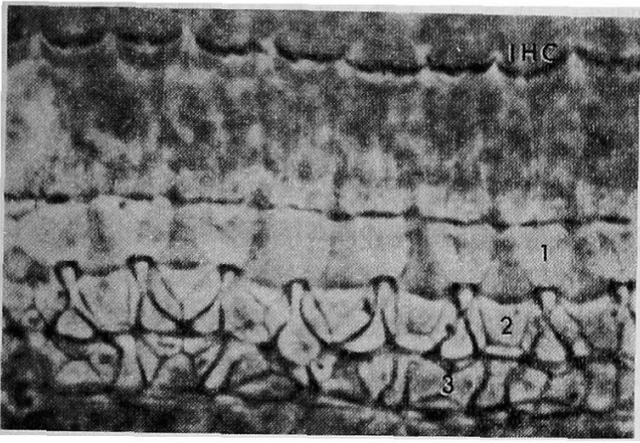

図 3 BUN 0.5mg/kg+KM $200 \mathrm{mg} / \mathrm{kg} 10$ 日間 投与 (BK-17), 基底回転。外有毛細胞は 3 列とも全て collapsed cell に陥ってい る. 内有毛細胞は正常。

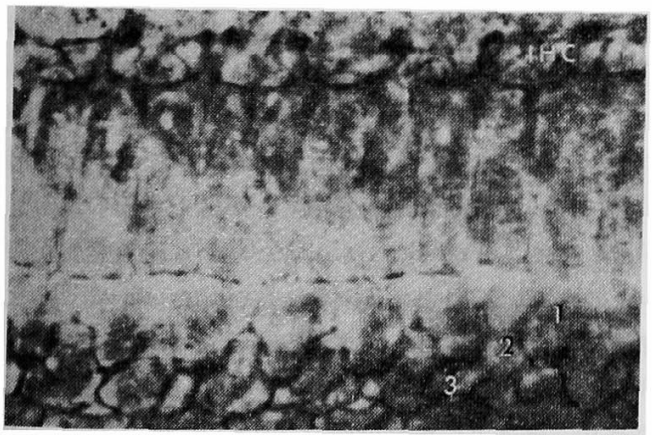

図 4 BUN 0.5mg/kg + KM 200mg/kg 10日間 投与 $(\mathrm{BK}-20)$, 基底回転. 外有毛細胞の 障害が高度なため, 細胞配列は明膫でな い.内有毛細胞\& collapsed cell に陥っ ている.

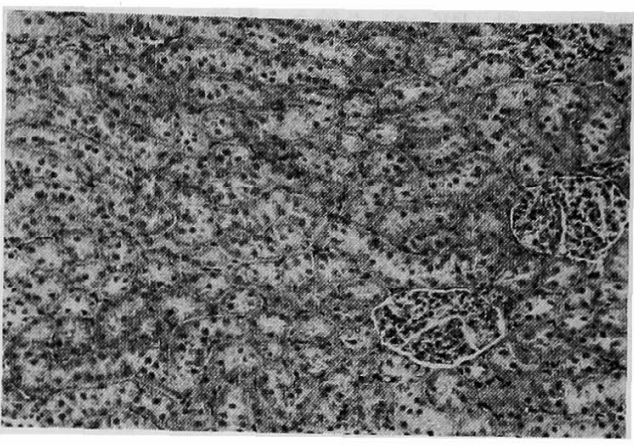

図 5 督組織像, 近位尿細管. BUN 0.75 mg/kg 10日間投与 (B-1). 特に異常所見を認め ない.

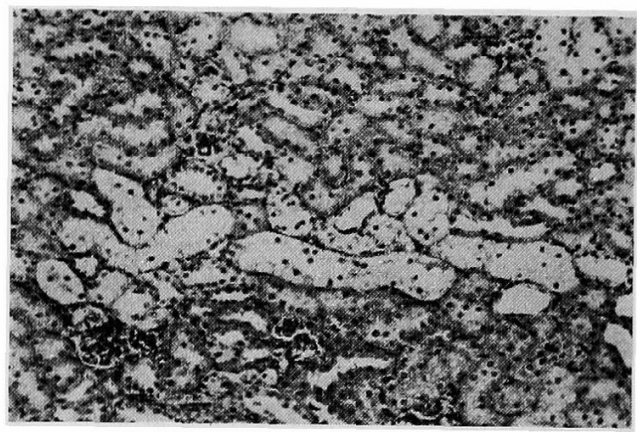

図 6 腎組織像，近位尿細管．BUN $0.5 \mathrm{mg} / \mathrm{kg}$ $+\mathrm{KM} 200 \mathrm{mg} / \mathrm{kg} 10$ 日間投与 (BK-13). 尿細管上皮は空胞化が著しく, 泡沫状を 呈し，核の減少がみられる

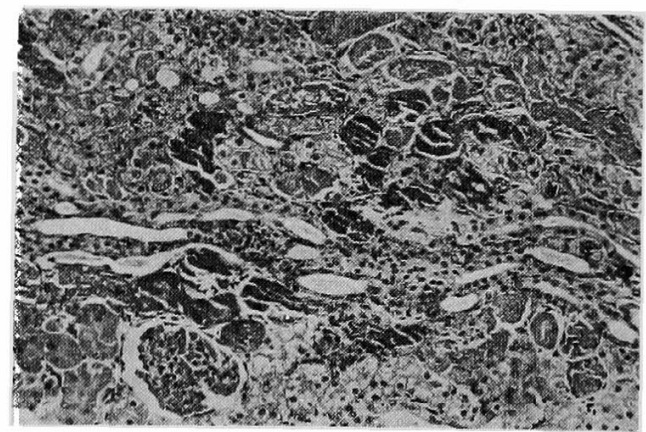

図 7 腎組織像, 近位尿細管. BUN $0.5 \mathrm{mg} / \mathrm{kg}$ $+\mathrm{KM} 200 \mathrm{mg} / \mathrm{kg} 10$ 日間投与 (BK-18). 尿細管上皮の変性・壞死が高度で, 石灰 沈着を伴った壊死物質の塞栓がみられ る。 
用群では1羽（BK-12）索除き全動物に，尿絸管上皮の 水腫性橵化, 核の消失, 硝子滴変性, 剝離, 凝固塐死, 石灰沈着など種々の障害像を認めた，障害が比較的軽度 のものでは，近位㽷細管の遠位部に限局しており，変性 性変化を主とするが，障害が高度になると障䟧は近位尿 細管全体におよび，上皮の壊死や石灰沈着が主な変化で あった。督障害は BUN 0.75mg/ $\mathrm{kg}$ 㐼用群が $0.5 \mathrm{mg} / \mathrm{kg}$ 仵用群より女高庭で，BUN $0.5 \mathrm{mg} / \mathrm{kg}$ 併用封の腎障㫪 が FM $30 \mathrm{mg} / \mathrm{kg}$ 併用の場合に澉していた（図 6，7).

全動物の繁障害の程度を図1に一括した，障害の程度

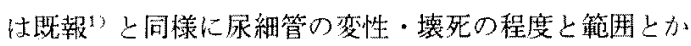
ら分類したが，その主な点は次の如くである。

\pm : 近位尿細管上皮の水腫性膨化，核の消失が政在性 にみられるもの。

+：士の変化が比較的びまん性にみられるもの，

H：+の変化に上皮の紧状壊死が加わってみられるも D.

H十：十と册との中間のもので疗細管上皮の变性や壊死 が広测に起きているが，な招正常に近い部分をかなり 残しているもの.

卅：近位尿細管上皮全体の壊死，さらには石灰化がび

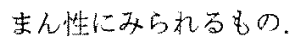

\section{考按}

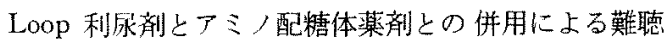
発現については，1969年 Mathog \& Klein ${ }^{103}$ のA と ア三八配糖体薬剂 (Streptomycin, KM, Neomycin) 併 用に上る3症例の報告にはじまり，它の後，いくつかの

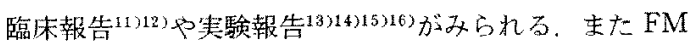
とアミノ配糖体薬膈との併用による難聴については， Quick $^{17)}$ の GM 併用に上る臨床報告がみられ，実験的 にも種々のアミ/配結体葙剂併用時の内耳障害について 報告されている(18)19) しかし BUNとアミノ配梼体薬威 との併用による内耳障害については，現在まで臨床的に も奉験的にむ報告されていない

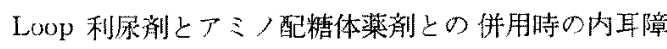
害については，次のよらなことが考えられてきた。す わち EA FM 住 Na, K.ATPase 阻害するが20), これらのATPase は繁のほかに血管条に多く存在して 打り，また KM む血管条のATPase を阻害することか $ら^{21)}$ ，二種薬剤の同一酵素系への阻害が内耳障害増強の

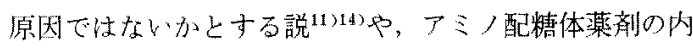
耳障害に対する物筫代謝阻恝作用に，利尿剤の膜ATPase 阻害作用主上した菒理作用の相加，あるいは利承剂に
よるアミ／配轱体薬剂の内耳人の高濃度の移行・停滞な どがその原因をなすといら考えがある坊 EA やFM の作用については，最近これらの利尿剤には $\mathrm{Na}, \mathrm{K}$. ATPase に対する特暴的抑制作用はないとの報告22233 や，腎での $\mathrm{Na}, \mathrm{Cl}$ の再吸收の阻害は $\mathrm{Cl} の$ active transport の抑制によるもので Na は passive との報 告2425〕もりこれらの点に関してはまだ定説をみてい ないようである。いずれにせよ二種薬剂併用時の内耳障 害には利㽷剤の内耳人の直接作用が重要な要素上考えら れてきた。

われわれば，単独では内耳障害老起こさない量の FM とアミ，配糖体菜剂上妾併用すると，高度の内耳障 害が惹起され，その際腎においても激烈な障害の発現才 る事実を叝告してきた，更に二種薬剤併用時の内耳障害 增強性については，FMによるアミ/配糖体薬剂の腎加 らの排泄阻害が重要な因子と考えここれに高度の腎障害 が加かって急速に悪循環が焦行していくものと考えた。 しかし FM の単独投与でも AP, CM, EP などの内耳 麗気現象に変化をおよぽすことが知られており，アミ， 配糖体薬剤との併用時の内耳障害增强性についても， FM の内耳への直接作用の関与昰えられた.

BUN は1971年に開発され，かが国では1976年から発 売されている新利尿剤で，FM き $\mathrm{EA}$ と同様に $\mathrm{Na}, \mathrm{Cl}$ の再吸収を抑制することにより利氺作用を発揮するいわ ゆるL Loop 利尿剂であるが，その利尿作用は FM の40 〜60倍あるといわれている2334．踟床的には BUNは注

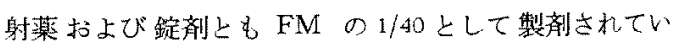
る. BUN の内耳への影響については，Brown》 はネコ の) cochlear $\mathrm{N}_{1}$ potential 指祭しした実験で，BUN の absolute ototoxic potency は FM 06.5倍である が，その利尿作用はFM の 40〜60倍もあることから， その relative ototoxic potency はFM の0.11 0.16に

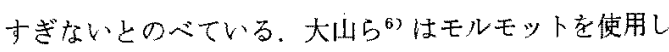
FM では 20mg/kg の静注で EP が低下するのに対して BUN では $2.5 \mathrm{mg} / \mathrm{kg}$ でも EP，CM に全く変化がこな いとのバている、また草刈ら”もモルモットの EP を指 標とした春験で，EP に影響を与える量は静注で BUN は $5 \mathrm{mg} / \mathrm{kg}$ 以上であるのに対して FM では $20 \sim 30 \mathrm{mg} / \mathrm{kg}$ であり，また EP が最低值を示す量は BUNは $30 \mathrm{mg} / \mathrm{kg}$ て FM は 50〜 100 mg/kg であると報告している。すふ わち利尿作用を考慮伅入れて比較するとBUNの電気生 理学的な内耳八の作用は FM の約 1/10kすぎないま た，佳藤ら $\left.{ }^{26}\right)$ は，モルモットを使用し，BUN0.1mg/kg， 
$0.2 \mathrm{mg} / \mathrm{kg}$ の 1 回注射および $0.01 \mathrm{mg} / \mathrm{kg}$ の28日閒の注射 で，耳介反射域值に変化をきたさず，また病理組織学的 にも内，外有毛細胞にも変化のみられないことから， BUN の耳毒性は非常に弱いものと推察している。䧗床 的にも，FM で難聴が生した患者に，代りに FM の 1/40のBUN を投与した結果, 難聴が消失ないし回復 したとの報告がある27り そこで今回このよ5に内耳障害 の少ないBUNを使用し：BUNの利尿作用をFM の利 尿作用と同等にして KM と併用した訳であるが，その 結果 FM 併用時にみられたと同㥞の高度の内耳障害が 惹起された.このことはLoop 利尿剤(FM 㧍よびBUN) 上 KM 併用時の内耳障害增強性は利尿荗のるつ利尿作 用上密接に関倸していることを推察させる。すなわち二 種薬剂併用時の内耳障害増強の原因については，Loop 利尿剂㧍上び KM のそれぞれの内聂に対方る作用が相 乗されたと考えるよりも，Loop 利展剂の繁への作用に よって，KM の腎からの排泄が阻害され，KM の血中 濃度が上昇することが重要な因子と考えられた。更にこ れに高度の腎障害が加わって急速に悪循環が谁行してい くものと思执れた。結局 BUN と KM の二種薬剂併用 時の内耳障害に果すBUNの役割についていえば，BUN の内耳人の作用よりも腎入の作用の方が、はるがに大て あり，士たるものであるうと考えられ，Loop 利拫郕上 アミ/配栫体薬剂併用時の内耳障害堌強性の原因につ、 てのこれまでのわれわれの推論を更にららずけるものと 考えられた。

BUN とアミ/配糖体薬剂との併用時の腎障害の増強 については，現在まで跕床的にも実験的にも報告がみら れない，Loop 利尿浏の腎に対する瑇性は，利尿作用と 不可分のものと考えられ，更にBUN の利尿作用に注著 しい動物種属差がみられるため283，毒性の梌討には各種 属の利尿作用を考慮に入れて検討する必要があるよらに 思われる。本寒験で用いた家乘については，その利尿作 用は大体イヌの $1 / 10$ ，マウスの10倍，ラットの100倍市 り28，ほぼヒトに近い利尿作用を有しているものと考觉 られる。BUN 单独投与群では, 腎仙病理組織学的検 索で著変はみられず，BUN 単独で敨高度の腎障害を起 こすに甠到らない上らである。

また $\mathrm{KM}$ の腎毒性については周知のと㧍りであるが， 既報での心゙たごとく，単独では相当量の投与でも重篤な 觜障害をきたすことはないようである。

すなわちをれぞれ単独では㹂障害を起こさない二種莧 剂でも、これらが併用され右と，さきに示したよらに高
度の障害を起こすことが明らかになった，难障害の程度 には，各動物により相当の個体差がみられたが，全身状 態悪化のため予定期間以内に固定せざるを得なかった動 物では，特に障害が謞度で，併用時の全身状態の悪化は 督不全によるためと推測された。近位的細管の変性壊死 で象徴される障害像汢，KM単独投与時や，FM 上 KM 併用時にみら机る障害像と類似して扔り，これらの間に 障害梙式の本質的な差異はないものと考えられる。

次に内耳障害と㹂障害との関係をみる, 内耳障害の 強いものでは，概して腎障害も強い傾向を示していた が，督障害の起こらないもの（BK.12）でむ内耳障害が みられまなた腎障害が軽度にも拘らず內耳障害が高度の もの（BK-20）もあることから，前述したように，内耳 障害は腎障害の結果生じたものではなく，KMの血中源 度の上昇にもとずくもので，腎障害恃これを更に增強さ せるものと考えられた。また觜障害の高度のものでも内 耳障害のないもの（BK-11）や，内耶障害の軽度のもの (BK-1) があることから，同一動物における内耳と腎の 易傷性洨，必ずしも平行寸るものではない上考文ら机 古.

以上，BUN 上 KM との併用時に高度の内耳と腎の 障害が惹起されることをのべたが，この薬剤相互作用 は，恐らく KM に限らず全てのアミ/配糖体薬剂に共 通するものと考えられた，BUNとFM との利尿作用を 考慮に入れて比較すると，BUNの内耳に対する作用は， FM 上りもはる加に低いといわれているにもかからら ず，KM上併用した場合の内耳障害の程度は，FMの場 合と同等に高度であり，また婜の変化についても同様で 京った。この事実は，併用時の内耳，督障害が利尿剂の もつ利尿作用と密接に関倸していることを強く示唆する しのである.吻論本研究は動物実駼であるから，その結 果を直ちに臨床に結びつけることは妥当でないかししれ ないが，臨末上BUNの投与に際しても，アミノ配糖体

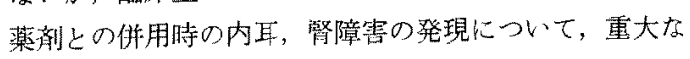
関心老払ら必要があることを強く蓖告するものと考え る.

\section{まと め}

新Loop 利尿剂BUN の利尿作用はFM O 40 60倍 で，内耳に対する作用は，利尿作用を考虑に入れると， FM の約 1/10にすぎないといわ机ているＦとＫM 併用封に高度の内耳，緊障害の惹起することを既報に拧 いて報告したが，今回は BUN の投与量を FMの1/40 抆よび1/60，すなわ方 BUN のもつ利尿效果をFM の 
それと同等にして，KM と併用した際の内耳障害を， FM 併用時のそれと比較し，Loop 利尿剂と KM 併用

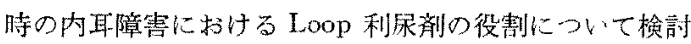
を行った。

1) BUN ゃ KM の单独投与で江外有毛細胞纪全〈障 害を起こさない量であっても，これらの二種薬剤死侀用 すると，外有毛細胞に高度の障害が惹起された。これら の障害の程度は，FM と KM. 併用時のそれに匹敵して wた。

2）一方，腎は二種薬剤併用時に高度の变性壞死を起こ し，その主病変忏近位尿細管にみられた，これらの障㕩

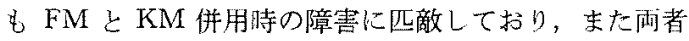
間に障害像の本碩的な差異はみられなかった。

3）すな⿰力口利层作用を考慮化入れて比較する上, BUN の内耳に対する作用は FM よりはるかに低い上いわれ ているが，KM と併用した場台の内耳障害は，FM の 場合上同等であり，また腎についても，FM 併用時にみ られたような高度の障害が惹起された。このことから， Loop 利尿凨上 KM 併用時の内耳，腎障害は，利尿㓮の もつ利尿作用と密接に関係していると考えられた。

4) 上記二種薬剂併用時の内耳拉上び腎に対する薬剂相 互作用は，恐らく KM K限らず，全てのアミ/配糖体

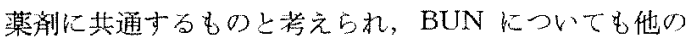
Loop 利尿剂と同椂了ミ/配糖体薬剂との併用時の内耳, 腎障害の発現について，充分な注意を払ら必要があるも のと考える。

\section{文献}

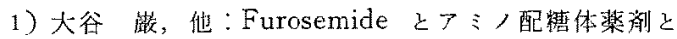
の併用火上る内耳・觜赫害の激烈化飞ついて。 Chemotherapy, 25;2348-2360, 1977.

2) Dstergaard, E.H. et al.: Pharmacological properties of 3-n-butylamino-4-phenoxyl-5-sulfamylbenzoic acid (Bumetanide), a new potent diuretic. Arneim.Forsch, 22 ; 66-72, 1972.

3) Olesen, K.H. et al.. Bumetanide, a new potent diuretic. Acta med. scand., 193; 119-131, 1973.

4) Davies, D.L. et al.: Renal action, therapeutic use, and pharmacokinectics of the diuretic bumetanide. Clin. pharmacol. ther., 15;141-155, 1974.

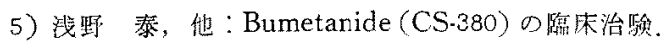
薬理と治撩。2；47-54，1974.

6）大山孔毁，他：血管条の機能飞ついて。内䎲生化 学, $5 ; 75-77,1974$.
7) Brown, R.D.: Cochlear $\mathrm{N}_{1}$ depression producer by the new "loop" diuretic, bumetanide, in cats Neuropharmacology, 14; 547-553, 1975.

8) Brown, R.D.: Effect of bumetanide on the posi tive endocochlear $\mathrm{d} c$ potential of the cat. Tox appl, pharmac., $38 ; 137-144,1976$.

9）草刈 潤，他：フィタードのモルモット内リンパ雷

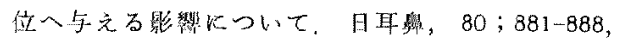
1977.

10) Mathog, R.H.\& Klein, W.J. Jr.: Ototoxicity of ethacrynic acid and aminoglycoside antibiodics in uremia. N. Engl. J. Med, 280;1223-1224 1969.

11) Johnson, A.H. \& Hamilton, C.H.: Kanamycin ototoxicity-possible potentiation by other drugs South Med. J., 63 ; 511-513, 1970.

12) Meriwether, W.D. et al.. Deafness following standard intravenous dose of ethacrynic acid. JAMA, 216;795-798, 1971.

13) West, $B, A$, et al.: Interaction of kanamycin and ethacrynic acid. Arch. Otolaryngol., 98; 32-37, 1973.

14) Prazma, J. et al.. Ethacrynic acid ototoxicity potentiation by kanamycin. Ann. Otol. Rhinol. Laryngol., $83 ; 111-118,1974$.

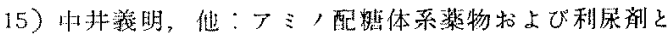
の併用以上る内施熊. Audiology Japan, $18 ； 290-$ 298,1975 .

16) Nakai, Y.: Combined effect of $3^{\prime}, 4^{\prime}$-dideoxykanamycin $B$ and potent diuretics on the cochlea. Laryngoscope. 87 ; 1548-1558, 1977.

17) Quick, C.A.: Hearing loss in patients with dialysis and renal transplants. Ann. Otol. Rhinol. Laryngol., 85; 776-\%90, 1976.

18) Brummett, R.E. et al.: Cochlear damage resulting from kanamycin and furosemide. Acta Otolaryngol., 80; 86-92, 1975.

19）中米義明，森本明子：アミ，配糖体系菜物扰よびフ

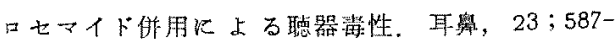
596, 1977.

20) Hook, J.B. \& Williamson, H.E.: Lack of correlation between natriuretic activity and inhibition of renal Na-K-activated ATPase. Proc. Soc. Exp. 
Biol \& Med., 120;358 360, 1965.

21) Iinuma, $T$. et al.: Passible effects of various ototoxic drugs upon the ATP-hydrolyzing system in the stria vascularis and spiral ligament of the guinea pig. Laryngoscope. $71 ; 22-26,1967$.

22) Kuijpers, W.\& Wilberts, D.P.C.: The effect of ouabain and ethacrynic acid on ATPase activities in the inner ear of the rat and guinea pig. ORL, $38 ; 321-327,1976$.

23) Thalman, R. et al.: Action of "loop" diuretics and mercurials upon the cochlea. Acta Otolaryngol., $83 ; 211-232,1977$.

24) Kokko, J.P. \& Rector, F.C. Jr.: Countercurrent multplication system without active transport in inner medulla. Kidney International, $2 ; 214-223$, 1972.
25) Burg, M.B. \& Green, N.: Function of the thick ascending limb of Henle's loop. Am. J. Physiol, $224 ; 659-668,1973$.

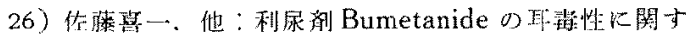

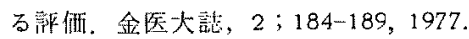

27) Bourke, E.: Furosemide, bumetanide, and ototoxicity. Lancet 1 ; 917-918, 1976.

28) Otsen, U.B.: The pharmacology of bumetanide. Acta pharmacol. et toxicol., 41 ; Suppl., 1972.

本諭文の要旨は，第22回オージージ一学会にて発表 lた.

(原㯖受村䧂和53.2.8日)

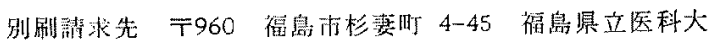

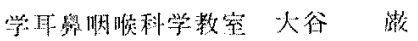

